\title{
Michal Szwast ${ }^{1}$
}

Uniwersytet Warszawski

ORCID ID: 0000-0001-9431-5908

\section{BEZCZYNNOŚĆ W PRZEDMIOCIE \\ ODEBRANIA ŚLUBOWANIA \\ OD RADCY PRAWNEGO. \\ GLOSA DO POSTANOWIENIA NACZELNEGOSĄDU \\ ADMINISTRACYJNEGO Z 17 LUTEGO 2016 R., II GSK 151/16}

\section{ABSTRACT}

Gloss to the judgement of the Polish Supreme Administrative Court of February 17, 2016 (case file no. II GSK 151/16, concerning the inaction on taking the oath from an attorney-at-law)

The subject of the gloss is the decision of the Polish Supreme Administrative Court concerning the admissibility of judicial control over inaction in the

1 Doktor nauk prawnych, adiunkt w Zakładzie Praw Człowieka WPiA UW, starszy specjalista w Naczelnym Sądzie Administracyjnym, wiceprezes zarządu Fundacji Edukacji Parlamentarnej, autor licznych publikacji naukowych z obszaru prawa konstytucyjnego, praw człowieka, prawa i postępowania administracyjnego i sądowoadministracyjnego. 
matter of taking the oath from an attorney-at-law, which determines the effectiveness of the constitutional personal right to a court. The content and arguments of the judgement have an impact on other procedures in which taking an oath is a necessary element of obtaining the right to practice a specific profession or activity. The author of the gloss expands the argumentation of the Polish Supreme Administrative Court on the necessity of pro-constitutional interpretation of the provisions of acts which expressis verbis do not provide for the right to submit a complaint against inaction in taking the oath from an attorney-at-law.

Keywords: taking an oath, Polish Supreme Administrative Court, attorney-at-law, pro-constitutional interpretation

Słowa kluczowe: odebranie ślubowania, Naczelny Sąd Administracyjny, radca prawny, wykładnia prokonstytucyjna

\section{Uwagi wprowadzające}

Glosowanym postanowieniem z 17 lutego 2016 r. (II GSK 151/16) Naczelny Sąd Administracyjny uchylił postanowienie Wojewódzkiego Sądu Administracyjnego w Warszawie z 17 września 2015 r. (VI SA/Wa 57/15) o odrzuceniu skargi K. S. na bezczynność dziekana rady okręgowej izby radców prawnych $\mathrm{w}$ W. w przedmiocie odebrania ślubowania. Orzeczenie to dotyka dość wąskiego, jak mogłoby się wydawać, problemu prawnego dopuszczalności zaskarżenia do sądu administracyjnego bezczynności dziekana okręgowej izby radców prawnych w przedmiocie odebrania ślubowania od radcy prawnego. Przeprowadzona analiza orzecznictwa dostępnego w Centralnej Bazie Orzeczeń Sądów Administracyjnych pokazuje bowiem, że sprawy tego typu nie były rozstrzygane ani przed wydaniem glosowanego orzeczenia, ani po nim. Rozstrzygnięcie to jest jednak istotne z co najmniej dwóch powodów. Po pierwsze wypowiada się o zakresie kontroli sądowoadministracyjnej, warunkującej skuteczność konstytucyjnego prawa podmiotowego do sądu, a po drugie jego treść promieniuje na inne procedury, w których elementem koniecznym do uzyskania prawa do wykonywania danego zawodu (działalności) jest złożenie ślubowania. 


\section{Stan faktyczny sprawy}

Stan faktyczny sprawy przedstawiał się w następujący sposób. W maju 2013 r. rada OIRP w W. podjęła uchwałę w sprawie wpisu skarżącej K. S. na listę radców prawnych. W czerwcu 2013 r. rada OIRP wznowiła postępowanie $\mathrm{w}$ sprawie wpisu, podnosząc, że $\mathrm{w}$ dacie podejmowania uchwały o wpisie nie miała informacji o okolicznościach świadczących o braku rękojmi należytego wykonywania zawodu przez skarżącą. W sierpniu 2013 r. rada OIRP podjęła uchwalę o uchyleniu uchwały z maja 2013 r. w sprawie wpisu skarżącej na listę radców prawnych. Uchwała ta została utrzymana w mocy uchwałą Prezydium Krajowej Rady Radców Prawnych. Minister Sprawiedliwości decyzją ze stycznia 2014 r. uchylił uchwały rady OIRP i Prezydium KRRP. Następnie WSA w Warszawie wyrokiem z 14 stycznia 2015 r. VI SA/Wa 1226/14 uchylił decyzję Ministra Sprawiedliwości oraz uchwałę Prezydium KRRP i uchwałę rady OIRP z sierpnia 2013 r. i stwierdził, że uchylone akty prawne nie podlegają wykonaniu. Prezydium KRRP wniosło od tego wyroku skargę kasacyjną, która w chwili orzekania przez WSA w Warszawie w sprawie bezczynności dziekana rady OIRP $\mathrm{w}$ W. oczekiwała na rozpoznanie przez NSA. Skarżąca złożyła wniosek o wyznaczenie terminu ślubowania, który został załatwiony odmownie, a następnie wezwała dziekana rady OIRP do dokonania czynności odebrania ślubowania. Dziekan rady OIRP w W. nie wyznaczył daty ślubowania i nie odebrał go od skarżącej.

Skarżąca wniosła do WSA w Warszawie o zobowiązanie dziekana rady okręgowej izby radców prawnych w W., na podstawie art. $149 \$ 1$ ustawy z 30 sierpnia 2002 r. - Prawo o postępowaniu przed sądami administracyjnymi (Dz.U. z 2012 r. poz. 270 ze zm., dalej jako: p.p.s.a.), do dokonania czynności polegającej na odebraniu ślubowania od radcy prawnego. Sąd pierwszej instancji odrzucił skargę na bezczynność, argumentując po pierwsze, że ustawa z 6 lipca 1982 r. o radcach prawnych (Dz.U. z 2015 r. poz. 507), wymieniając rodzaje spraw, które mogą podlegać kontroli sądu administracyjnego (m.in. ustalenie wyniku egzaminu wstępnego na aplikację radcowską, ustalenie wyniku egzaminu radcowskiego, skreślenie aplikanta radcowskiego z listy aplikantów), przewiduje, że nie każdy akt podejmowany przez samorząd radcowski względem jego członków podlega kognicji sądów administracyjnych, 
co się tyczy w szczególności czynności odebrania ślubowania. Po drugie ślubowanie od radcy prawnego odbiera dziekan rady, który nie będąc organem samorządu radców prawnych (art. 42 ust. 1 ustawy o radcach prawnych a contrario), nie jest organem działającym w zakresie administracji publicznej, którego bezczynność można zaskarżyć.

W skardze kasacyjnej skarżąca zarzuciła postanowieniu WSA w Warszawie m.in. naruszenie przepisów postępowania, tj. art. $3 \$ 1, \$ 2$ pkt 4 i 8 oraz $\$ 3$ w zw. z art. $58 \$ 1$ p.p.s.a. poprzez ich błędną wykładnię polegającą na uznaniu, że akt ślubowania przez osobę wpisaną na listę radców prawnych składany dziekanowi rady okręgowej izby radców prawnych nie jest inną czynnością z zakresu administracji publicznej dotyczącą uprawnień lub obowiązków wynikających z przepisów prawa, że bezczynność w podjęciu tej czynności nie podlega kognicji sądów administracyjnych, że jest to inna przyczyna odrzucenia skargi, a w konsekwencji błędne zastosowanie w sprawie art. 58 p.p.s.a., jak również art. 45 ust. $1 \mathrm{w}$ zw. $\mathrm{z}$ art. 77 ust. 2 Konstytucji RP poprzez naruszenie zasady prawa do sądu, a tym samym uniemożliwienie skarżącej dochodzenia jej praw.

NSA, uchylając powyższe postanowienie sądu pierwszej instancji, stanął na stanowisku, że „zakres działania sądów administracyjnych został ukształtowany bardzo szeroko. Obejmuje on całokształt działalności administracji publicznej pod względem zgodności z prawem, chyba że ustawa stanowi inaczej (art. $1 \$ 2$ ustawy z 25 lipca 2002 r. - Prawo o ustroju sądów administracyjnych)". Jak wskazywał NSA, akt lub czynność, na które przysługuje skarga do sądu administracyjnego (art. $3 \$ 2$ p.p.s.a.), charakteryzują się tym, że mają charakter publicznoprawny, są podejmowane $\mathrm{w}$ sprawie indywidualnej, skierowane są do oznaczonego podmiotu oraz dotyczą uprawnienia lub obowiązku tego podmiotu. Samo zaś uprawnienie lub obowiązek, którego akt lub czynność dotyczy, winno być określone w przepisie prawa powszechnie obowiązującego. Podstawowym wyznacznikiem poddania danego aktu lub czynności kognicji sądu administracyjnego jest to, że zostaje on dokonany w ramach pełnienia przez podmiot funkcji administracji publicznej i w tym kontekście należy ocenić czynność odebrania ślubowania od radcy prawnego. Powołując się na wcześniejsze orzecznictwo, NSA podkreślił, że organy samorządu zawodowego są organami administracji publicznej 
w ujęciu funkcjonalnym ${ }^{2}$, posiadają wynikające $\mathrm{z}$ ustaw uprawnienia do wykonywania zadań z zakresu administracji publicznej (m.in. orzekanie o nadawaniu uprawnień do wykonywania zawodu) i w tym zakresie podejmują czynności nie tyle w ramach wewnętrznych, korporacyjnych spraw, ile niejako na zewnątrz administracji, są więc ściśle związane obowiązującym prawem publicznym ${ }^{3}$. NSA przyjął, że kontrola wykonywania przez samorządy zawodowe ich zadań z zakresu administracji publicznej (w szczególności przyznawania uprawnień do wykonywania zawodu) należy do właściwości sądów administracyjnych. Zgodnie bowiem $\mathrm{z}$ art. 23 ustawy o radcach prawnych dla powstania prawa do wykonywania zawodu radcy prawnego niezbędne jest zrealizowanie dwóch warunków: wpis na listę radców prawnych i złożenie ślubowania. W tym kontekście NSA zauważył, że o ile ustawa o radcach prawnych $\mathrm{w}$ art. $31-31^{2}$ szczegółowo reguluje warunki oraz tryb dokonania wpisu na listę radców prawnych (przewidując, że w wypadku niepodjęcia uchwały w sprawie wpisu na listę lub niepodjęcia uchwały w przedmiocie odwołania od tej uchwały zainteresowanemu służy skarga do sądu administracyjnego), o tyle w odniesieniu do drugiego warunku niezbędnego do uzyskania uprawnienia do wykonywania zawodu radcy prawnego ustawa stanowi jedynie, że ślubowanie odbiera dziekan rady okręgowej izby radców prawnych prowadzącej listę radców prawnych, na którą wpisany został radca (art. 27 ust. 2). Tym samym ustawa o radcach prawnych nie reguluje kwestii zaskarżenia czynności odebrania ślubowania lub ewentualnie bezczynności dziekana w tym przedmiocie. Zdaniem NSA nie można $\mathrm{z}$ tego jednak wywieść, że sąd administracyjny nie posiada kognicji w sprawie odebrania ślubowania. NSA podkreślił, że skoro złożenie ślubowania jest niezbędnym warunkiem do uzyskania prawa do wykonywania zawodu radcy prawnego, to jego odebranie przez dziekana rady OIRP stanowi czynność z zakresu administracji publicznej dotyczącą uprawnień lub obowiązków wynikających z przepisów prawa, o której mowa w art. $3 \$ 2$ pkt 4 p.p.s.a. W konsekwencji można złożyć, na podstawie art. $3 \$ 2$ pkt 8 p.p.s.a., skargę na bezczynność dziekana

2 Wyrok NSA z 11 lipca 2006 r., II OSK 333/06. Orzeczenie dotyczyło samorządu pielęgniarek i położnych.

3 Postanowienie NSA z 31 stycznia 2006 r., II OSK 1459/05. 
polegającą na nieodebraniu ślubowania. W ocenie NSA „przyjęcie odmiennego stanowiska czyniłoby iluzoryczną kontrolę sądów administracyjnych nad procedurą przyznawania przez samorząd radców prawnych uprawnienia do wykonywania zawodu. Tymczasem z samej ustawy o radcach prawnych wynika dążenie ustawodawcy do zapewnienia efektywnej kontroli sądowej w tym zakresie”. NSA nie zgodził się również ze stanowiskiem sądu pierwszej instancji, jakoby dziekan rady OIRP nie miał być organem administracji publicznej wskutek niewymienienia go w ustawie o radcach prawnych w katalogu organów samorządu radcowskiego. W tym zakresie NSA w glosowanym postanowieniu stwierdził, że skoro czynność odebrania ślubowania jest czynnością z zakresu administracji publicznej, to podmiot, który dokonuje tej czynności, powinien zostać uznany w tym zakresie za organ administracji publicznej.

\section{Ocena orzeczenia}

Omawiane postanowienie NSA należy przyjąć z aprobatą. Wpisuje się ono w słuszną tendencję szerokiego rozumienia pojęcia sprawy sądowoadministracyjnej, zapewniającego realizację prawa do sądu administracyjnego, chroniącego przed arbitralnością w rozstrzyganiu o sytuacji prawnej jednostki przez organ administracji publicznej ${ }^{4}$. Warto jednak szerzej rozwinąć wątek konieczności objęcia zakresem kognicji sądów administracyjnych bezczynności dziekana rady OIRP w zakresie odebrania ślubowania od radcy prawnego z perspektywy realizacji norm konstytucyjnych w zakresie prawa do sądu, jak również pokazać wagę i szerszy kontekst tego orzeczenia.

Odebranie przez dziekana rady okręgowej izby radców prawnych ślubowania od radcy prawnego jest czynnością materialno-techniczną, niezbędną jednak do powstania uprawnienia do wykonywania tego zawodu. Jak stanowi art. 23 ustawy o radcach prawnych, prawo wykonywania

$4 \mathrm{Z}$ nowszych publikacji na ten temat zob. M. Kowalski, Prawo do sądu administracyjnego. Standard międzynarodowy i konstytucyjny oraz jego realizacja, Warszawa 2019, s. 324 i nast. 
zawodu radcy prawnego powstaje $\mathrm{z}$ chwilą dokonania wpisu na listę radców prawnych i złożenia ślubowania. Nie można zatem wykonywać zawodu radcy prawnego bez wpisu na listę radców prawnych albo nie złożywszy ślubowania ${ }^{5}$. Innymi słowy, w art. 23 ustawy o radcach prawnych ustanowiono koniunkcję przesłanek niezbędnych do nabycia prawa do wykonywania zawodu radcy prawnego ${ }^{6}$. Co więcej, zgodnie z $\$ 7$ ust. 1 uchwały KRRP w sprawie regulaminu prowadzenia list radców prawnych i list aplikantów radcowskich z 30 stycznia 2010 r., zaświadczenie stwierdzające prawo do wykonywania zawodu radcy prawnego oraz legitymację wydaje się radcy prawnemu wpisanemu na listę radców prawnych po złożeniu przez niego ślubowania?.

Jak stanowi art. 27 ust. 2 ustawy o radcach prawnych, ślubowanie odbiera dziekan rady okręgowej izby radców prawnych prowadzącej listę radców prawnych, na którą wpisany został radca prawny. Należy stanąć na stanowisku, że do odebrania ślubowania konieczna jest inicjatywa dziekana rady OIRP, który - po wpisie radcy prawnego na listę radców prawnych - powinien wezwać radcę prawnego do złożenia ślubowania i określić termin jego odebrania. Radca prawny samodzielnie - z własnej inicjatywy - nie może skutecznie złożyć takiego ślubowania ${ }^{8}$.

Biorąc pod uwagę te dwie okoliczności (złożenie ślubowania jako warunek sine qua non powstania uprawnienia do wykonywania zawodu radcy prawnego oraz decydującą i sprawczą rolę dziekana rady OIRP w odebraniu ślubowania) należy opowiedzieć się za koniecznością kontroli sądowej nad czynnością odebrania ślubowania oraz ewentualną bezczynnością lub przewlekłością w postępowaniu dziekanów w tym zakresie.

5 R. Stankiewicz, Komentarz do art. 23 ustawy o radcach prawnych [w:] Ustawa o radcach prawnych. Komentarz 2018, red. T. Scheffler, wyd. 1, Legalis 2021.

6 K. Wojtczak, Zawód i jego prawna reglamentacja. Studium z zakresu materialnego prawa administracyjnego, Poznań 1999, s. 179, cyt. za R. Stankiewicz, Komentarz do art. 23 ustawy o radcach prawnych [w:] Ustawa o radcach prawnych. Komentarz 2018, red. T. Scheffler, wyd. 1, Legalis 2021.

7 Uchwała nr 110VII/2010 Krajowej Rady Radców Prawnych w sprawie regulaminu prowadzenia list radców prawnych i list aplikantów radcowskich z 30 stycznia 2010 r. (K.Rad.Prawn.nr 1, poz. 110).

8 Zob. wyrok NSA z 4 października 1999 r., II SA 1120/99, w którym wskazano, że „ślubowanie wymagane przez art. 27 ustawy jest ściśle powiązane z inicjatywą odbierającego go organu, bez której radca prawny nie może tej czynności dokonać”. 
Jak trafnie zasygnalizował w glosowanym postanowieniu NSA, ustawa o radcach prawnych nie reguluje expressis verbis prawa do zaskarżenia do sądu administracyjnego czynności odebrania ślubowania lub ewentualnie bezczynności dziekana w tym przedmiocie, natomiast $\mathrm{w}$ art. 31-31 ${ }^{2}$ szczegółowo reguluje warunki oraz tryb dokonania wpisu na listę radców prawnych (przewidując, że w wypadku niepodjęcia uchwały w sprawie wpisu na listę lub niepodjęcia uchwały w przedmiocie odwołania od tej uchwały zainteresowanemu służy skarga do sądu administracyjnego). Jednakże wnioskowanie a contrario, które przeprowadził w glosowanej sprawie WSA w Warszawie, nie było dopuszczalne. Zamiast niego należało lukę prawną w przepisach ustawy o radcach prawnych zastąpić odpowiednią wykładnią art. $3 \$$ pkt 4 i 8 p.p.s.a., przyjmując, że czynność odebrania ślubowania radcy prawnego stanowi podlegającą kontroli sądu administracyjnego „inną czynność z zakresu administracji publicznej dotyczącą uprawnień lub obowiązków wynikających z przepisów prawa" i w konsekwencji dopuszczalna jest skarga na bezczynność dziekana rady OIRP w tym przedmiocie. NSA trafnie przyjął takie stanowisko, dość jednak lakonicznie argumentując, że „przyjęcie odmiennego stanowiska czyniłoby iluzoryczną kontrolę sądów administracyjnych nad procedurą przyznawania przez samorząd radców prawnych uprawnienia do wykonywania zawodu. Tymczasem z samej ustawy o radcach prawnych wynika dążenie ustawodawcy do zapewnienia efektywnej kontroli sądowej w tym zakresie".

Rozwijając argumentację NSA, należy wskazać, że w omawianej sprawie doszło $w$ istocie do zastosowania przez sąd prokonstytucyjnej wykładni art. 3 \$ pkt 4 i 8 p.p.s.a. w związku z art. 23 i art. 27 ust. 2 ustawy o radcach prawnych. Przepisom tych dwóch ustaw nadano treść, która realizuje podmiotowe prawo dostępu do sądu, dekodowane $\mathrm{z}$ art. 45 ust. 1 i art. 77 ust. 2 Konstytucji RP. Wyrok WSA w Warszawie, odrzucający skargę na bezczynność w przedmiocie odebrania ślubowania od skarżącej, prowadził bowiem do zamknięcia drogi sądowej, która była konieczna dla oceny legalności działania organu administracji publicznej - dziekana rady OIRP w sprawie naruszonej wolności wyboru i wykonywania zawodu przez skarżącą (art. 65 ust. 1 Konstytucji RP).

$\mathrm{W}$ tym miejscu należy zauważyć, że jednym z podstawowych elementów treści prawa do sądu jest prawo „każdego” do „rozpatrzenia 
sprawy” przez sąd (prawo dostępu do sądu, zwane prawem do zainicjowania postępowania sądowego). Ustalenie znaczenia pojęcia „sprawy” użytego w art. 45 ust. 1 Konstytucji RP ma „podstawowe znaczenie dla określenia zakresu i pojemności prawa do sądu"9. Pojęcie sprawy nie zostało zdefiniowane w Konstytucji RP. Nie jest także jednoznacznie rozumiane w orzecznictwie i doktrynie prawniczej. Na podstawie analizy orzecznictwa TK można sformułować kilka zasad dotyczących rozumienia pojęcia sprawy: przede wszystkim autonomiczności pojęcia sprawy użytego w art. 45 Konstytucji RP względem rozumienia tego pojęcia na gruncie ustaw zwykłych oraz jego szerokiego rozumienia i zakazu jego zawężającej wykładni. Trybunał Konstytucyjny podjął rozważania na temat zakresu przedmiotowego prawa do sądu już w wyroku z 10 maja 2000 r. (K 21/99). Wskazał w nim, że prawo do sądu obejmuje „wszelkie sytuacje - bez względu na szczególowe regulacje proceduralne, w których pojawia się konieczność rozstrzygania o prawach danego podmiotu (w relacji do innych równorzędnych podmiotów lub w relacji do władzy publicznej), a jednocześnie natura danych stosunków prawnych wyklucza arbitralność rozstrzygania o sytuacji prawnej podmiotu przez drugą stronę tego stosunku”. Do kategorii praw, o których rozstrzyga sąd, „należą nie tylko te, które są objęte bezpośrednio gwarancjami konstytucyjnymi, ale także wszelkie inne prawa, których istnienie wynika z całokształtu obowiązujących regulacji prawa materialnego, niesprzecznych z przepisami Konstytucji RP"10. W każdym zaś przypadku gwarancje prawa do sądu mogą być odnoszone jedynie do sytuacji, w których przepisy prawa materialnego przewidują prawną ochronę określonych wartości ${ }^{11}$. Na gruncie kluczowego w omawianej sprawie prawa dostępu do sądu ujawnia się szczególna relacja pomiędzy art. 45 ust. 1 i art. 77 ust. 2 Konstytucji RP. Interpretacja art. 77 ust. 2 Konstytucji RP przez TK sprowadza się do konkluzji, że zakaz zamykania ustawą drogi sądowej do dochodzenia gwarantowanych konstytucyjnie wolności lub praw

9 Wyroki TK: z 14 marca 2005 r., K 35/04; z 18 maja 2004 r., SK 38/03; z 10 maja 2000 r., K 21/99.

10 Wyroki TK: z 27 maja 2008 r., SK 57/06; z 14 marca 2005 r., K 35/04; z 10 maja 2000 r., K 21/99; z 3 lipca 2008 r., K 38/07.

11 Wyrok TK z 18 maja 2004 r., SK 38/03. 
ma charakter bezwzględny ${ }^{12}$. Innymi słowy, ustawodawca przy spełnieniu warunków ograniczeń praw i wolności wynikających z art. 31 ust. 3 Konstytucji RP może ograniczyć dostęp do sądu w przypadku praw i wolności, których nie gwarantuje Konstytucja RP. Natomiast ograniczenia w zakresie realizacji prawa do sądu nie mogą być tego rodzaju, by pozbawiły jednostkę ochrony sądowej w sytuacji naruszenia wolności i praw konstytucyjnych ${ }^{13}$. Podkreśla się przy tym, że art. 77 ust. 2 znajduje zastosowanie nie tylko w wypadkach, gdy ustawa wyłącza wprost prawo do zainicjowania postępowania przed sądem, ale także wówczas, gdy mimo braku wyraźnego wyłączenia przepis ustawy lub znajdująca się w ustawie luka prawna prowadzą do identycznego rezultatu ${ }^{14}$.

Przenosząc te rozważania natury konstytucyjnej na grunt omawianej sprawy, należy uznać, że NSA trafnie uznał odebranie ślubowania od radcy prawnego za inną czynność z zakresu administracji publicznej dotyczącą uprawnień lub obowiązków wynikających z przepisów prawa i tym samym objął ją zakresem pojęcia sprawy sądowoadministracyjnej. Przeciwne stanowisko prowadziłoby w istocie do naruszenia podmiotowego prawa do sądu. Jeśli bowiem sprawa dotyczy uzyskania uprawnienia do wykonywania zawodu radcy prawnego, to organy samorządu radcowskiego oraz dziekan rady OIRP działają $\mathrm{w}$ tej procedurze jako organy administracji publicznej w znaczeniu funkcjonalnym: władczo rozstrzygając o sytuacji prawnej podmiotu wobec nich zewnętrznego. Legalność ich działania czy też bezczynności musi być poddana kontroli sądu administracyjnego w celu realizacji prawa do sądu przez osobę, której prawa (w tym przypadku związane z wolnością wyboru i wykonywania zawodu, również wolnością działalności gospodarczej) zostały ograniczone. Skoro zaś dla wykonywania zawodu radcy prawnego konieczny jest zarówno wpis na listę, jak i odebranie ślubowania, to czynności zmierzające do realizacji obu tych przesłanek muszą być poddane kontroli sądowej. Luka prawna w zakresie braku unormowania w ustawie o radcach prawnych expressis verbis prawa złożenia skargi na czynność odebrania ślubowania lub bezczynność w tym zakresie musi być

12 Wyrok TKz 18 lipca 2011 r., K 25/09.

13 Tamże.

14 Tamże. 
zatem uzupełniona przez odpowiednią prokonstytucyjną wykładnię art. $3 \$ 2$ pkt 4 i 8 p.p.s.a.

Jakkolwiek omawiana sprawa dotyczyła bezczynności dziekana rady OIRP w odebraniu ślubowania radcy prawnego, to $\mathrm{w}$ mojej ocenie nie ma przeszkód, aby uznać, że w pełni dopuszczalne byłoby wniesienie również skargi na przewlekłe prowadzenie postępowania w przedmiocie odebrania ślubowania radcy prawnego (art. $3 \$ 2$ pkt 8 p.p.s.a.). Kwestia rozgraniczenia zakresu pojęć bezczynności i przewlekłego prowadzenia postępowania jest od dawna przedmiotem kontrowersji i niejednoznaczności w orzecznictwie i piśmiennictwie ${ }^{15}$. Na potrzeby niniejszej glosy można upraszczająco za M. Kotulskim przyjąć, że przez pojęcie przewlekłego prowadzenia postępowania należy rozumieć sytuację, gdy organowi wprawdzie nie można zarzucić bezczynności, gdyż nie minął jeszcze termin załatwienia sprawy albo prawo nie przewiduje żadnego terminu, np. dla dokonania czynności, lecz postępowanie jest prowadzone w sposób nieefektywny przez wykonywanie czynności w dużym odstępie czasu, mnożenie czynności dowodowych ponad potrzebę wynikającą z istoty sprawy bądź wykonywanie czynności pozornych ${ }^{16}$. Teza o dopuszczalności wniesienia do sądu administracyjnego skargi na przewlekłe prowadzenie przez dziekana rady OIRP postępowania w przedmiocie odebrania ślubowania wydaje się mieć znaczenie w szczególności w czasie trwania stanu epidemii, w którym różne organy administracji publicznej uzasadniają swoje niespieszne działania ograniczeniami sanitarno-epidemicznymi i - wskazywanymi często jako ich konsekwencja - trudnościami kadrowo-organizacyjnymi.

Tezy zawarte $\mathrm{w}$ glosowanym postanowieniu mają istotne znaczenie dla szeregu innych postępowań, w których złożenie ślubowania jest warunkiem sine qua non uzyskania uprawnienia do wykonywania określonego zawodu lub objęcia określonego stanowiska, a jednocześnie

15 Zob. uwagi T. Wosia: Komentarz do art. 3 p.p.s.a. [w:] T. Woś, M. Knysiak-Sudyka, M. Romańska, Prawo o postępowaniu przed sądami administracyjnymi. Komentarz, LEX 2021, pkt 106.

16 M. Kotulski, Zaskarżalność bezczynności i przewlekłości do sądu administracyjnego, „Casus” 2014, nr 73, s. 12-14, cyt. za: T. Woś, Komentarz do art. 3 p.p.s.a. [w:] T. Woś, M. Knysiak-Sudyka, M. Romańska, Prawo o postępowaniu przed sądami administracyjnymi. Komentarz, LEX 2021, pkt 106. 
przepisy ustaw szczegółowych normujących zasady nabycia tych uprawnień expressis verbis nie stanowią o możliwości złożenia skargi do sądu administracyjnego na taką czynność czy też ewentualnie bezczynność lub przewlekłe prowadzenie postępowania. Skutki omawianego postanowienia można transponować na status większości profesji zaliczanych do tak zwanych zawodów zaufania publicznego, przykładowo: adwokata ${ }^{17}$, notariusza $^{18}$ i zastępcy notarialnego ${ }^{19}$, kuratora zawodowego ${ }^{20}$, komornika sądowego $^{21}$, rzecznika patentowego ${ }^{22}$, biegłego rewidenta ${ }^{23}$, doradcy podatkowego $^{24}$, doradcy restrukturyzacyjnego ${ }^{25}$ czy też farmaceuty ${ }^{26}$.

Kierując się tym orzeczeniem i sformułowanymi w niniejszej glosie tezami o konieczności prokonstytucyjnej wykładni przepisów danej ustawy szczegółowej i art. 3 \$ 2 pkt 4 i 8 p.p.s.a., należy opowiedzieć się za dopuszczalnością kontroli sądowej w zakresie czynności polegającej na odebraniu ślubowania od osoby powołanej na dany urząd, wpisanej na listę wykonujących dany zawód czy rodzaj działalności. Biorąc pod uwagę treść prawa dostępu do sądu, należy przyjąć, że podmioty odbierające ślubowanie, którego złożenie jest niezbędnym elementem do wykonywania określonego zawodu, są organami administracji publicznej i ich działalność (również bezczynność i przewlekłość w prowadzeniu postępowania) w tym zakresie musi być poddana kontroli sądowej pod

17 Art. 5 w zw. z art. 69a ustawy z 26 maja 1982 r. - Prawo o adwokaturze, t.j. Dz.U. z 2020 r. poz. 1651 .

18 Art. 15 ustawy z 14 lutego 1991 r. - Prawo o notariacie, t.j. Dz.U. z 2020 r. poz. 1192, dalej: prawo o notariacie.

19 Art. 76\$1-3 prawa o notariacie.

20 Art. 6 z 27 lipca 2001 r. o kuratorach sądowych, t.j. Dz.U. z 2020 r. poz. 167.

21 Art. 17 z 22 marca 2018 r. o komornikach sądowych, t.j. Dz.U. z 2021 r. poz. 850.

22 Art. 18 w zw. z art. 22 ustawy z 11 kwietnia 2001 r. o rzecznikach patentowych, t.j. Dz.U. z 2021 r. poz. 944.

23 Art. 7 w zw. z art. 4 ust. 2 pkt 8 ustawy z 11 maja 2017 r. o biegłych rewidentach, firmach audytorskich oraz nadzorze publicznym, t.j. Dz.U. z 2020 r. poz. 1415.

24 Art. 8 ustawy z 5 lipca 1996 r. o doradztwie podatkowym, t.j. Dz.U. z 2020 r. poz. 130.

25 Art. 15 ustawy z 15 czerwca 2007 r. o licencji doradcy restrukturyzacyjnego, t.j. Dz.U. z 2020 r. poz. 242.

26 Art. 16 i 17 ustawy z 10 grudnia 2020 r. o zawodzie farmaceuty, Dz.U. z 2021 r. poz. 97. 
względem zgodności z prawem. Odebranie ślubowania z reguły bowiem wieńczy długi, wieloetapowy i sformalizowany proces uzyskania uprawnienia do wykonywania danego zawodu, w którym zwykle wydawane są jeszcze przed ślubowaniem rozstrzygnięcia władcze (decyzje administracyjne) podlegające na mocy konkretnych postanowień ustaw szczegółowych kontroli sądowej. Nie może być zatem tak, że niewykonywanie przez organ administracji publicznej wieńczącej owe procedury materialno-technicznej czynności odebrania ślubowania zamknie (bez możliwości kontroli sądowej) drogę do wykonywania danego zawodu. 


\section{Bibliografia}

Kotulski M., Zaskarżalność bezczynności i przewlekłości do sądu administracyjnego, „Casus” 2014, nr 73.

Kowalski M., Prawo do sadu administracyjnego. Standard międzynarodowy $i$ konstytucyjny oraz jego realizacja, Warszawa 2019.

Stankiewicz R., Komentarz do art. 23 ustawy o radcach prawnych [w:] Ustawa o radcach prawnych. Komentarz 2018, red. T. Scheffler, wyd. 1, Legalis 2021 .

Wojtczak K., Zawód i jego prawna reglamentacja. Studium z zakresu materialnego prawa administracyjnego, Poznań 1999.

Woś T., Komentarz do art. 3 p.p.s.a. [w:] T. Woś, M. Knysiak-Sudyka, M. Romańska, Prawo o postępowaniu przed sądami administracyjnymi. Komentarz, LEX 2021. 